Lysozyme is an ubiquitous enzyme found in most biological secretions and leukocytes. This study was aimed at investigating its interaction with other inflammatory mediators on mucosa surfaces, particularly the complement system. Lysozyme has been shown in our present study, to inhibit the haemolytic activity of serum complement in a dose-dependent fashion, when tested within the levels present in normal and inflamed breast-milk samples, and other mucosal secretions. This represents a new antiinflammatory action of lysozyme in relation to the serum complement, and the exact mode of the in teraction need further studies.

Key words: Human lysozyme, Complement system, Inflammation

\section{A novel anti-inflammatory activity of lysozyme: modulation of serum complement activation}

\section{O. Ogundele}

Department of Immunology, Georg-August

University, Kreuzbergring 57, D-37075 Göttingen,

Germany; Present address: Department of

Chemistry, Georg-August University, Göttingen,

Germany

Correspondence to: Thiestr. 3, D-37081 Göttingen,

Germany

Tel/Fax: (+49) 551373692

Email: mogundel@yahoo.com

Internet: lemming.stud.fh-heilbronn.de/ - ogundele

\section{Introduction}

Lysozyme is an acid-and heat-stable enzyme that is abundant in the breast-milk and in most other mucosal body-fluids. ${ }^{1}$ Lysozyme catalyses the hydrolysis of $\beta(-1,4-)$ linkage between $\mathrm{N}$-acetylglucosamine and N-acetylmuramic acid in the bacterial cell wall. The enzyme lyses mostly Gram-positive and a few Gram-negative bacteria or induces their aggregation. ${ }^{2}$ In addition, it possesses prominent anti-inflammatory properties.

Lysozyme has been show $\mathrm{n}$ to inhibit chemotax is of activated leukocytes. Other anti-inflammatory functions of lysozyme include inhibition of mitogeninduced lymphoblastogenesis and autologus mixed lymphocyte reaction (at concentrations ranging between 1 and $10 \mu \mathrm{g} / \mathrm{ml}){ }^{3}$

Its interaction with the complement $(\mathrm{Cp})$ system has so far been found to be indirect, by an inhibition of PMN response towards complement-derived chemotaxins. Our present studies have shown that it is also capable of directly modulating the entire activation of $\mathrm{Cp}$ reaction cascade. The exact mechanis $\mathrm{m}$ for this inhibition is however, yet to be fully examined. Lysozyme, some milk proteins, such as alpha lactalbumin, and low-molecular-weight ligands, such as citrates and phosphates, are known to have high affinity binding sites for calcium, ${ }^{4}$ and may therefore act as inhibitors of complement indirectly, by chelating the divalent ions required for complement activation. The inhibitory effect of lysozyme might also be related to its ability to degrade certain glycoprotein components of native Cp factors.

The serum Cp system consist of at least 19 proteins, mostly in pre-activated enzymatic forms, activated in a multi-step cascade reaction via either the classical or alternative pathways. The classical pathway is activated mainly by antigen-antibody complexes (IgG or IgMmostly) starting with Clq, Clr, Cls, C4 and C2, and eventually leading to the activation of $\mathrm{C} 3$ by cleavage into $\mathrm{C} 3 \mathrm{a}$ and $\mathrm{C} 3 \mathrm{~b}$. The alternative pathway (APC) utilizes active sites (such as are present on zymosan, yeast, cobra venom, most Gram-negative bacteria, sheep erythrocytes and human cells deficient in the expression of membrane regulatory molecules) in the presence of properdin, serum factors $\mathrm{B}$ and $\mathrm{D}$, to activate C3. This step unifies the two pathways and proceeds uniformly thereafter to the formation of (C5b-9) membrane attack complexes (MAC), capable of inserting into biological membranes and producing cell lysis and death. APC activating surfaces are characterized by possession of structures which restrict access to inhibitory factor $\mathrm{H}$ to deposited $\mathrm{C} 3 \mathrm{~b}$, thereby amplifying the formation of further $\mathrm{C} 3 \mathrm{~b}$ in the presence of factor $B$.

\section{Materials and methods}

\section{Buffers}

Gelatin veronal buffered saline $\left(\mathrm{GVB}^{2+}\right)$ and sucrose gelatin veronal-buffered saline $\left(\mathrm{SGVB}^{2+}\right)$ with $\mathrm{Ca}^{2+}$ 
and $\mathrm{Mg}^{2+}$ were prepared as described by Mayer. $\mathrm{GVB}^{2-}$ buffer containing $10 \mathrm{mM}$ ethylene diacetyl ethylamine (EDTA) was used as the stopping solution. Sucrose-GVB ${ }^{2+}$ was utilized for the serum complement assay in place of $\mathrm{GVB}^{2+}$ buffer, with ionic strength of 0.065 and 0.149 respectively.

\section{Purified human lysozyme}

Purified lysozyme crystals was obtained from Serva Feinbiochemica-Heidelberg, Germany. It was dissolved in $\mathrm{SGVB}^{2+}$ and added to serum complement assays in final concentrations ranging from 50 to $1500 \mu \mathrm{g} / \mathrm{ml}$.

\section{Sensitized sheep red blood cells}

Sheep red blood cells (SRBC) (ORAW 30/31) obtained from Behringwerke, Marburg, Germany were washed twice in $\mathrm{GVB}^{2+}$ buffer and resuspended in the same buffer. The SRBC concentration was standardized sphectrometrically by adding $100 \mu \mathrm{l}$ of the SRBC suspension to $1.9 \mathrm{ml}$ water and reading the absorbance at $541 \mathrm{~nm}\left(\mathrm{~A}_{541}\right)$ with a spectrophotometer (Stasar III Gilford Instrument Laboratories, Inc., Oberlin, Ohio). $\mathrm{GVB}^{2+}$ was added to the SRBC until the $\mathrm{A}_{541} \mathrm{w}$ as 0.468 , corresponding to an ap proximate cell suspension of $1 \times 10^{9} / \mathrm{ml}$.

A sensitized cell suspension was prepared by a dropw ise addition of an equal volume of anti-Forsman haemolysin (diluted 1:300 in $\mathrm{GVB}^{2+}$ containing $20 \mathrm{mM}$ EDTA) to the previously prepared SRBC suspension. The cells were incubated at $37^{\circ} \mathrm{C}$ for $30 \mathrm{~min}$ and at $0-2^{\circ} \mathrm{C}$ for a further $30 \mathrm{~min}$. The cells were then washed once in $\mathrm{SGVB}^{2+}$ and resuspended in this buffer. A final suspension of $5 \times 10^{8}$ cells $/ \mathrm{ml}$, obtained by an equal addition of an equal volume of buffer, was employed in the test assays.

\section{Normal human serum haemolytic assay}

Serum samples were obtained from 10 healthy blood donors. A micro-modification of the standard haemolytic assay was used for the assessment of serum complement activity. A 1:20 dilution of serum was prepared, different volumes $(12.5-100 \mu \mathrm{l})$ of which was pipetted into the assay tubes, as well as $40 \mu \mathrm{l}$ of sensitized SRBC, to obtain a total reaction volume of $375 \mu \mathrm{l}, \mathrm{SGVB}^{2+}$ buffer was used for the serum assay, incubating the mixture for $60 \mathrm{~min}$ at $37^{\circ} \mathrm{C}$, with occasional mixing. After pelleting the remaining intact cells, $200 \mu \mathrm{l}$ of each supernatant was pipetted into a 96-well flat-bottomed microtitre plates (Greiner Labortechnik, Frickenhausen, Germany) and the amount of the released haemoglobin recorded by a plate sphectrophotometer (MR 700 microplate reader, Dynatech Instruments, Inc., Torrance, California) at a test wavelength of 410 against a reference wavelength of 630 . The degree of lysis produced was obtained from the equation

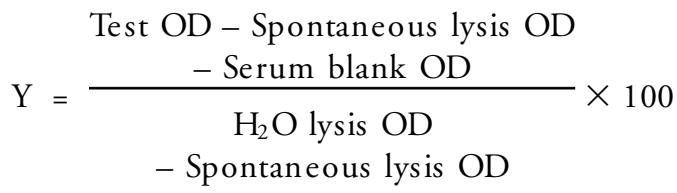

\section{Assays of serum complement inhibition by lysozyme}

Using the modified $\mathrm{CH} 50$ assay as described above, a constant volume of serum, containing approxmately one $\mathrm{CH} 50$ unit, and SRBC, were pipetted into assay tubes. Lysozyme was added before incubation of the the reaction mixtures, at final concentrations ranging from 50 to $1500 \mu \mathrm{g} / \mathrm{ml}$.

\section{Result}

Lysozyme was added to the serum as a source of $\mathrm{Cp}$ in $\mathrm{CH} 50$ whole $\mathrm{Cp}$ assays. Concentrations ranging from 50 to $1500 \mu \mathrm{g} / \mathrm{ml}$ were added, corresponding to expected physiological and pathological levels of lysozyme in the colostrum, mature or inflamed breastmilk, as well as other normal and inflamed body fluids. Lysozyme was found to inhibit the whole serum complement activity, mainly the classical pathway tested by $\mathrm{CH} 50$ assays, in a dose-dependent fashion (Fig. 1). At low concentrations corresponding to physiological levels, the inhibitory effect of lysozyme was relatively minimal. The inhibition thereafter rises sharply with increasing concentrations, within pathological ranges.

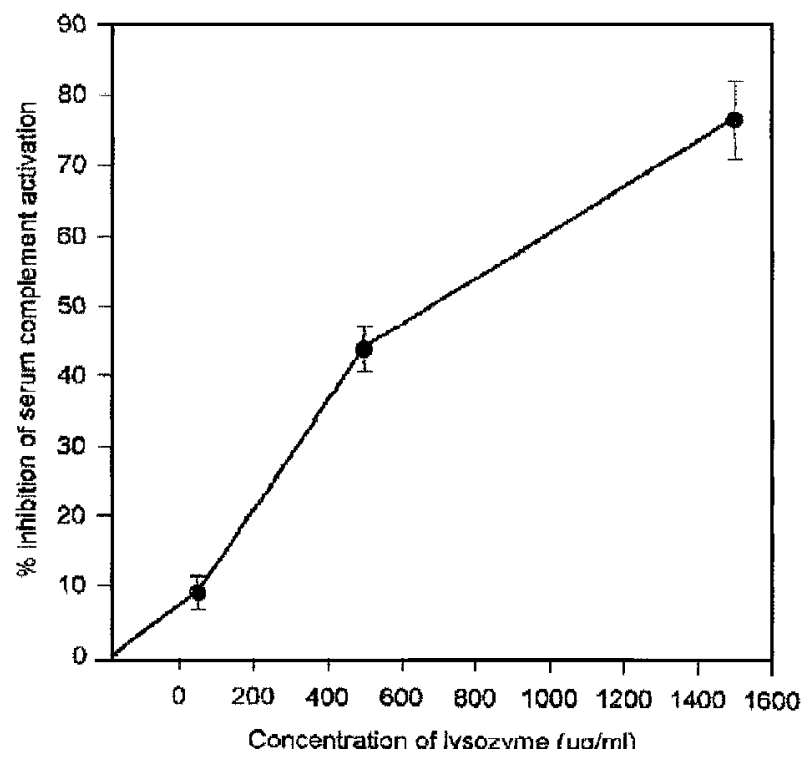

FIG. 1. Inhibitory effect of human Iysozyme on serum complement activation. $\bullet$ \% inhibition of serum complement activation (average $\pm \operatorname{SEM}, n=2$ ). 


\section{Discussion}

Despite widespread notions about insignificant roles of the inflammatory processes of the Cp system in mucosal secretions, ${ }^{5}$ the Cp system might still represent a major anti-microbial armoury on mucosal surfaces. A recent series of studies have demonstrated in vitro $\mathrm{Cp}$-mediated bacteriolytic activities against a serum-sensitive Escharichia coli, Staphylococcus aureus and $S$. epidermidis in human breast-milk (HBM). Furthermore, non-immune mechanisms of Cp activation have been demonstrated in the mucosal secretions of the lacrimal gland, suggesting that the wellknown inhibition of classical pathways of $\mathrm{Cp}$ activation at these mucosal sites by secretory components such as lactoferrin, could still be circumvented. In the HBM, apart from the $\mathrm{Cp}$ and free fatty acids (FFA), most of the other anti-mic robial components of $\mathrm{HBM}$ are bacteriostatic. Since bactericidal FFA are also present in the artificial formula feeds, and they do not seem to contribute to the protection of the formulafed infants, the Cp system should therefore be regarded as a potentially significant source of contribution to the observed resistance of breast-fed infants against infection.

Lysozyme was found to inhibit the classical pathway of serum complement activity in a dose-dependent fashion, particularly within the pathological ranges. The levels of both mucosal lysozyme and $\mathrm{Cp}$ components are known to increase during periods of infection. This would suggest that the mucosal Cp might be actively involved in bacteriolysis, opsonization and modulation of immune responses at mucosal surfaces, in the absence of full-blown inflammation, to protect the body against the constant threat of foreign invaders. The presence of anti-inflammatory secretory components would then serve to protect the tissues against secondary damage during acute overwhelming infections, where excessive inflammatory reactions of the $\mathrm{Cp}$ would be undesirable.

\section{References}

1. Reitamo S, Klockars M, Adinolfi-M, Osserman EF. Human lysozyme (origin and distribution in health and disease). Ric Clin Lab 1978; 8: 211-231.

2. Witholt B, Heerikhuizen HV, De Leij L. How does lysozyme penetrate through the bacterial outer membrane? Biochim Biophys Acta 1976; 443 $534-544$.

3. Gordon LI, Douglas SD, Kay NE, Yamada O, Osserman EF, Jacob HS. Modulation of neutrophil function by lysozyme. Potential negative feedback system of inflammation. J Clin Invest 1979; 64: 226-232.

4. Aramini JM, Drakenberg T, Hiraoki T, Ke Y, Nitta K, Vogel HJ. Calcium-43 NMR studies of calciumbinding lysozymes and alphatactalbumins. Biochem istry 1992; 31: 6761-6768.

5. Goldman AS, Goldblum RM, Hanson LA. Anti-inflammatory systems in human milk. Adv Exp Med Biol 1990; 262: 69-76.

ACKNOWLEDGEMENTS. The author is extremely grateful to the German Academic Exchange Services (DAAD) which provided sponsorship for th is study. The author is also greatly indebted to Professors Otto Götze and Thompsson, for their kind supervision and encouragement during this period. The kind assistance of Dr R. Giessler, who painstakingly reviewed the manuscript and provided helpful comments is hereby highly appreciated.

\section{Received 31 July 1998; \\ accepted in revised form 6 August 1998}




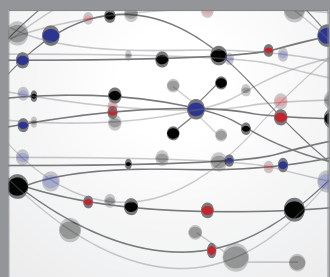

The Scientific World Journal
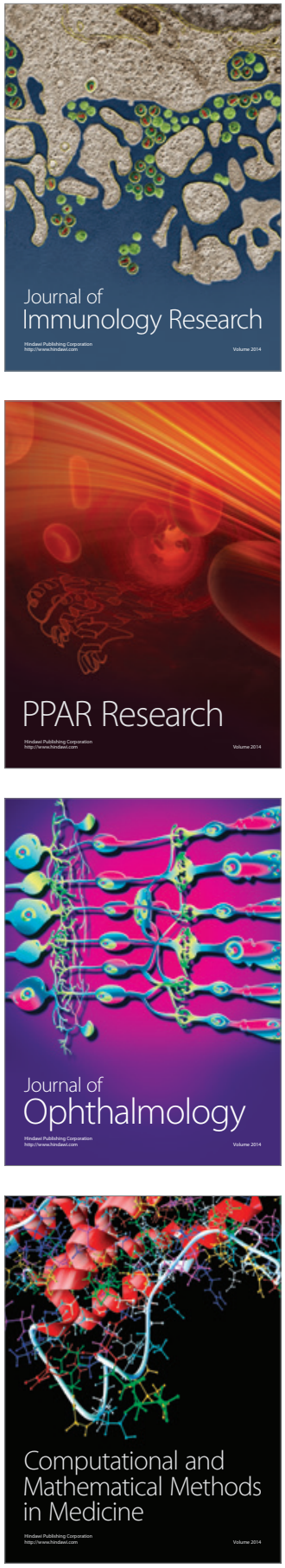

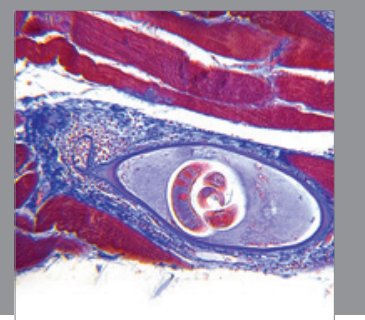

Gastroenterology

Research and Practice
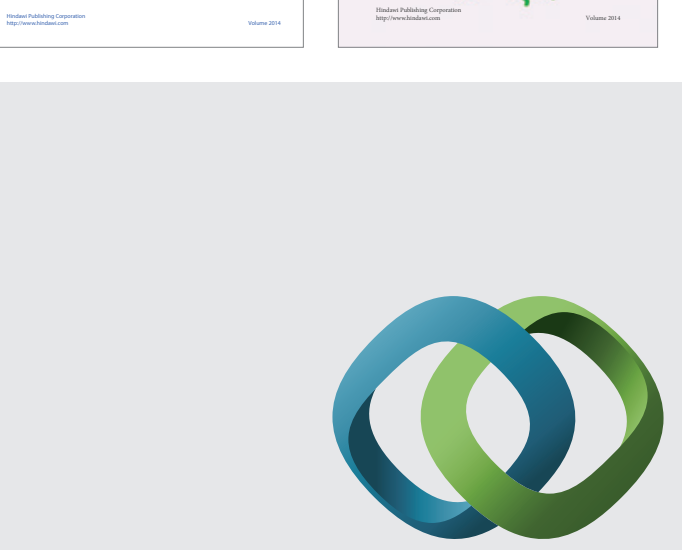

\section{Hindawi}

Submit your manuscripts at

http://www.hindawi.com
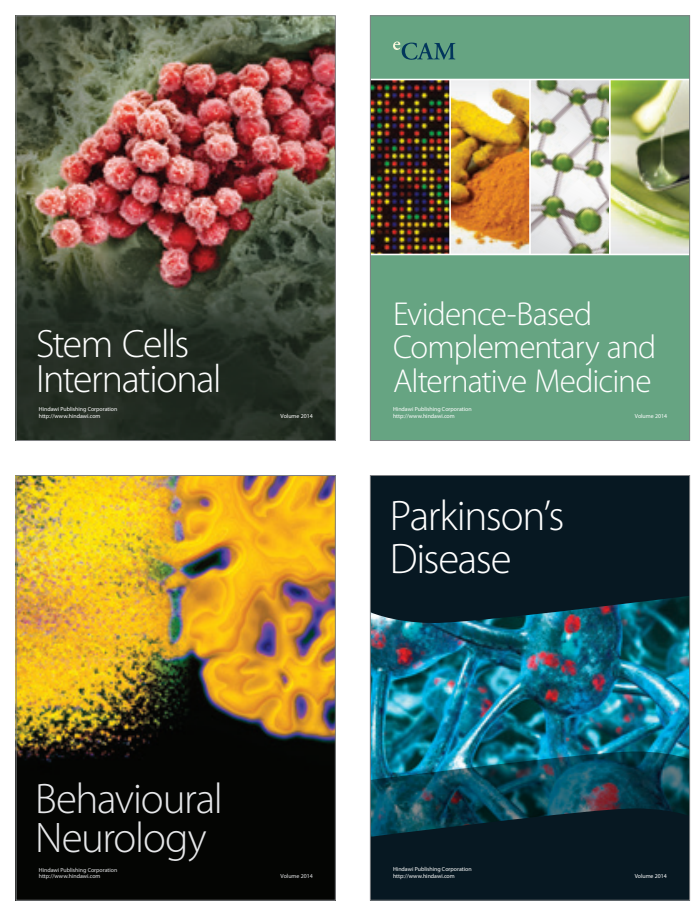

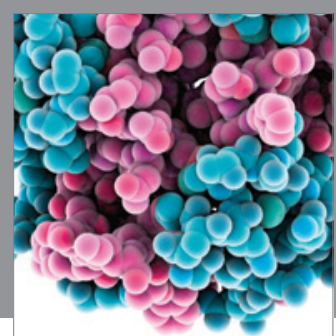

Journal of
Diabetes Research

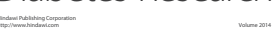

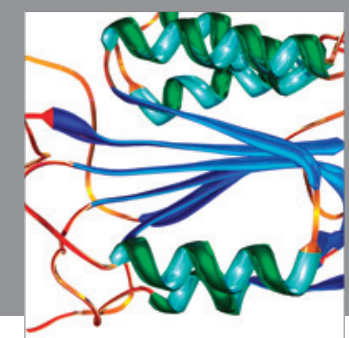

Disease Markers
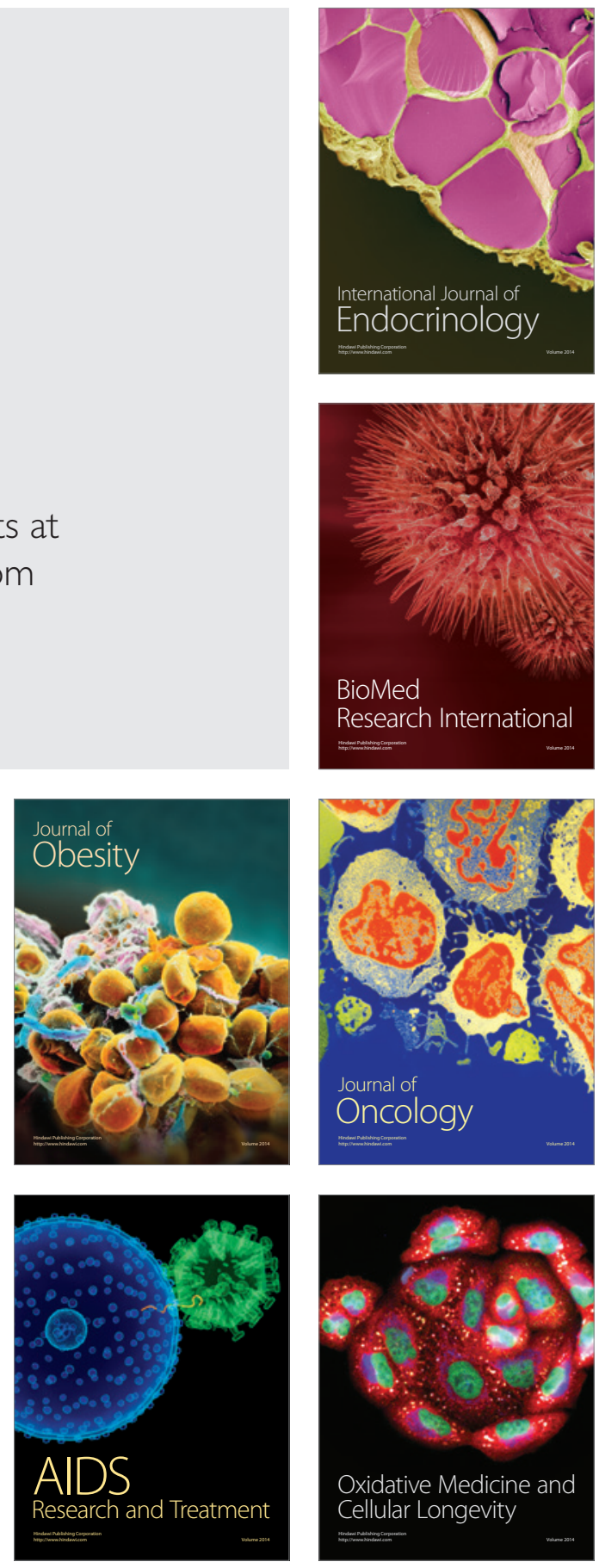